\title{
Screening of Promising Genotypes of Clusterbean against Colletotrichum capsici under Field Condition
}

\author{
Deepak Kumar Verma*, Rajni Singh Sasode and Amol Ramesh Harne
}

Department of Plant Pathology, COA, RVSKVV Gwalior, Madhya Pradesh, 474001, India

*Corresponding author

\section{A B S T R A C T}

\section{Keywords}

Anthracnose, Disease severity, Screening, Immune, Susceptible

Article Info

Accepted: 22 January 2019 Available Online: 10 February 2019
Anthracnose of clusterbean caused by Colletotrichum capsici is widespread problem limiting the profitable cultivation depending on the weather condition. A Total fifteen entries including the checks were evaluated under field condition during kharif 2017 for their reaction against anthtracnose of clusterbean. Out of these, none of genotype was found immune, five as resistance (HG 563, RGC 1066, RGC 1033, HG 2-20, GAUG-1502), Five as moderately resistant (X-10, RGr 16-2, GAUG 1304, CAZG-15-5, RGr-17-4), three genotypes as susceptible (CAZG-15-7, GAUG-1501, RGr-17-2 and two genotypes as highly susceptible (RGr 16-7, M-83) reaction against $C$. capsici.

\section{Introduction}

Clusterbean (Cyamopsis tetragonoloba L.Taub.), commonly known as guar, has come to be recognized as one of the most important commercial crop of arid and semiarid regions of India. The crop affected by several diseases out of these anthracnose caused by Colletortichum capsici is one of the major disease causes huge losses depending on weather condition. Because of lack of disease resistant varieties, management strategies are the major constraints in crop production. Out of all disease control methods, the planting of disease resistant varieties is the most effective because it leaves no fungicides residue in food or the environment and is constantly effective and generally compatible with other disease management measures. Unfortunately many of the existing released varieties of clusterbean are showing the signs of susceptibility to $C$. capsici. Several varieties exhibited resistance to this pathogen at the time of release, but this tolerance have broken down with time. Therefore screening was undertaken to evaluate a number of entries against anthracnose of clusterbean.

\section{Materials and Methods}

A field trial was conducted to determine the resistance levels in the promising genotypes which were developed at Agriculture 
Research Farm of Department of Plant Pathology, Gwalior during kharif 2017-18.

A total fifteen promising entries including checks were evaluated for their reaction against Colletotrichum capsici. The severity of anthracnose was assessed using a disease rating scale 0 to 9 given by Mayee and Datar (1986).

The data on disease incidence was recorded periodically at 30 and 60 days after sowing. The variation of different treatment was tested for the significance using randomized block design with two replications.

\section{Results and Discussion}

Effort was made to locate resistance sources and their utilization in breeding program are essential to manage the disease long run. It was revealed From Table 1 that among the fifteen genotypes evaluated, none of the genotype was found immune. five as resistance (HG 563, RGC 1066, RGC 1033, HG 2-20, GAUG-1502), Five as moderately resistant (X-10, RGr 16-2, GAUG 1304, CAZG-15-5, RGr-17-4), three genotypes as susceptible (CAZG-15-7, GAUG-1501, RGr17-2) and two genotypes as highly susceptible (RGr 16-7, M-83) reaction against $C$. capsici. .

Table.1 Screening of promising entries against anthracnose of clusterbean under field condition

\begin{tabular}{|c|c|c|c|c|c|c|}
\hline S.N. & VARIETY & $\begin{array}{c}\text { PDI } \\
\mathbf{3 0}\end{array}$ & $\begin{array}{l}\text { on } \\
\text { DAS }\end{array}$ & \multicolumn{2}{|c|}{$\begin{array}{l}\text { PDI on } \\
45 \text { DAS }\end{array}$} & REACTION \\
\hline 1 & HG 563 (ch) & 15.2 & $(22.94)^{*}$ & 28 & $(31.94)^{*}$ & $\mathrm{R}$ \\
\hline 2 & RGC 1066 & 18.4 & $(25.40)$ & 29.6 & $(32.96)$ & $\mathrm{R}$ \\
\hline 3 & $\mathrm{X}-10(\mathrm{AVT}-1)$ & 28 & (31.94) & 48.8 & $(44.31)$ & MR \\
\hline 4 & RGC 1033 (ch) & 19.2 & $(25.98)$ & 41.6 & $(40.16)$ & $\mathrm{R}$ \\
\hline 5 & HG 2-20 (ch) & 12.8 & (20.96) & 25.6 & $(30.39)$ & $\mathrm{R}$ \\
\hline 6 & RGr 16-2(AVT-1) & 16 & (23.48) & 42.4 & $(40.62)$ & MR \\
\hline 7 & CAZG-15-7 & 22.4 & (28.24) & 64 & $(53.14)$ & S \\
\hline 8 & GAUG 1304(AVT-1) & 20.8 & (27.13) & 55.2 & $(47.99)$ & MR \\
\hline 9 & GAUG-1501 & 29.6 & (32.96) & 80 & $(63.44)$ & $\mathrm{S}$ \\
\hline 10 & RGr 16-7(AVT-1) & 33.6 & $(35.42)$ & 82.6 & $(65.35)$ & HS \\
\hline 11 & RGr-17-2 & 30.4 & $(33.46)$ & 80.8 & $(64.01)$ & S \\
\hline 12 & CAZG-15-5 & 20.8 & (27.13) & 43.2 & $(41.09)$ & MR \\
\hline 13 & RGr-17-4 & 14.4 & $(22.30)$ & 59.2 & $(50.30)$ & MR \\
\hline 14 & GAUG-1502 & 17.6 & $(24.80)$ & 30.4 & $(33.46)$ & $\mathrm{R}$ \\
\hline \multirow[t]{3}{*}{15} & M-83 & 40.2 & (39.34) & 87.7 & $(69.47)$ & HS \\
\hline & SEM & 1.36 & & 0.77 & & \\
\hline & $\mathrm{CD}$ & 3.92 & & 2.35 & & \\
\hline
\end{tabular}

* Values in parenthesis are arcsine transformed values 
Fig.1 Screening of clusterbean cultivars against $C$. capsici f.sp. cyamopsicola

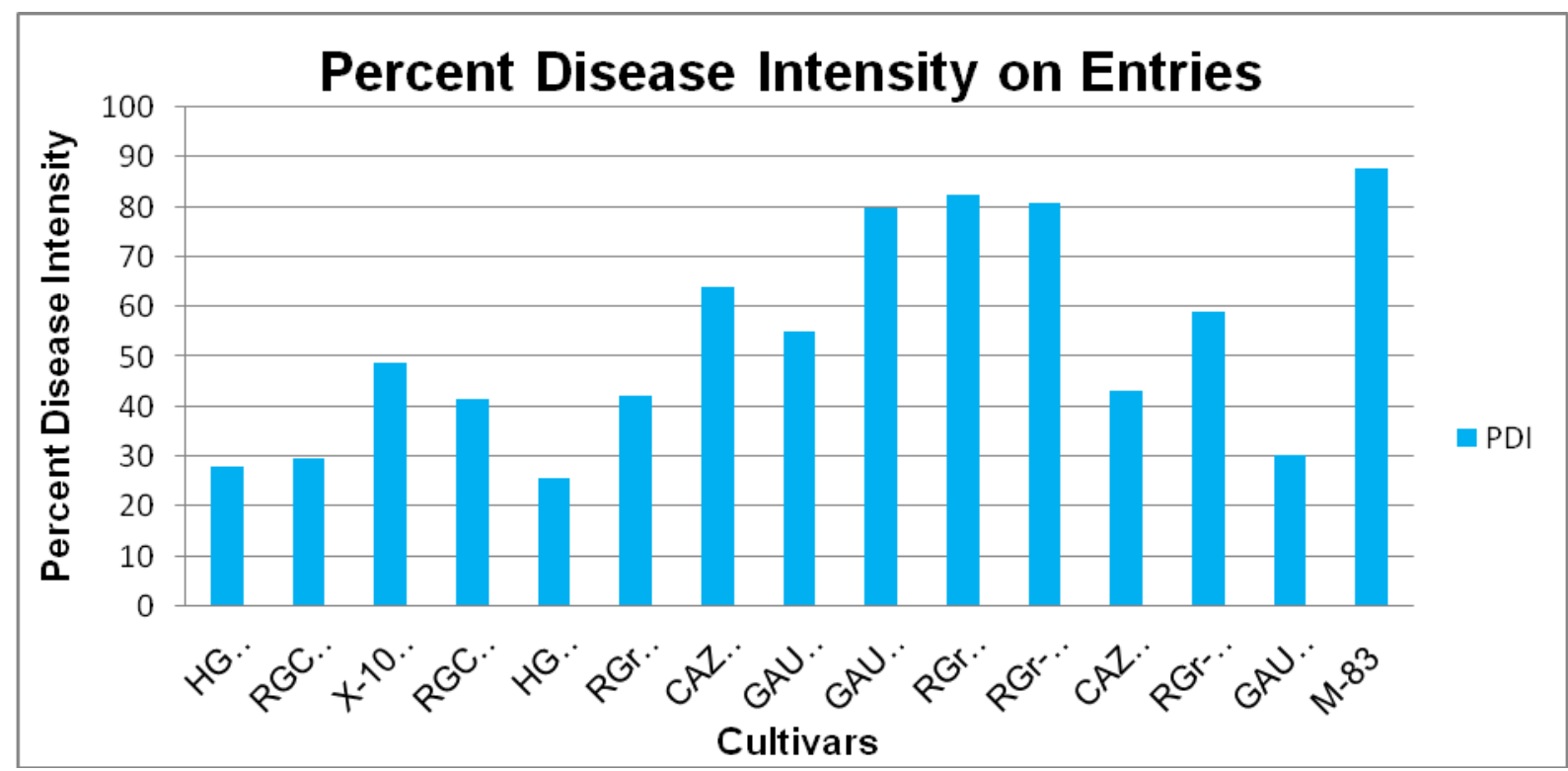

There is no commercial resistance cultivar of clusterbean against anthracnose so far (Fig. $1)$.

It can be concluded that five resistance genotypes identified HG 563, RGC 1066, RGC 1033, HG 2-20 and GAUG-1502 can be exploited for breeding programme. Several workers done a similar experiment on development of host plant resistance in different crops (Madhusudhan, 2002; Rathaiah and Sharma, 2004; Laxman, 2006).

\section{References}

Laxman R., 2006. Studies on leaf spot of Greengram caused by Colletotrichum truncatum (Schw.) Andrus and Moore. M. Sc. (Agri.) Thesis, Univ. Agric. Sci., Dharwad, Karnataka, India.

Madhusudhan, B.S., 2002. Studies on soybean anthracnose caused by Colletotrichum truncatum (Schw.) Andrus and Moore. M. Sc. (Agri.) Thesis, Univ. Agric. Sci., Bangalore, Karnataka, India.

Mayee, C.D. and Datar, V.V., 1986 "Phytopathometry". Technical Bulletin-I, Marathawada Agricultural University, Parbhani, India, 146 p.

Rathaiah, Y. and Sharma, S.K., 2004. A new leaf spot disease on mungbean caused by Colletotrichum truncatum, J. Mycol. Pl. Pathol. 34(2).

\section{How to cite this article:}

Deepak Kumar Verma, Rajni Singh Sasode and Amol Ramesh Harne. 2019. Screening of Promising Genotypes of Clusterbean against Colletotrichum capsici under Field Condition. Int.J.Curr.Microbiol.App.Sci. 8(02): 3002-3004. doi: https://doi.org/10.20546/ijcmas.2019.802.350 